\title{
エレクトロスピニング法 ナノファイバーの応用展開
}

\section{三好孝則 MIYOSHI Takanori} 帝人株式会社

\section{1. はじめに}

近年，ナノテクノロジーの進展に伴って，ナノファイ バーに関する関心が高まっている.

ナノファイバーの特徵の一つとして, 大きな比表面積 が挙げられる．表面はバルクと大きく異なる物性を有す ることが知られていることから，ナノファイバーは従来 予想されなかった様々な機能を新たに発現するのではな いかと期待されている11.

我々は，ナノファイバー作製法の一つであるエレクト ロスピニング法に着目し, 再生医療用途 ${ }^{2)}$ をはじめとし て，様々なアプリケーションについて検討している。本 稿では，エレクトロスピニング法に関する概要と，その 有害化学物質分解除去への応用に関する我々の最近の研 究成果について紹介する。

\section{2. エレクトロスピニング法}

エレクトロスピニング法とは，高分子溶液または溶融 状態の高分子に高電圧を印加することで繊維を紡糸する 方法である.

この技術は，1930年代に既に特許 ${ }^{3)}$ が出されている， 古くから知られた技術であるが，1990年代に入ってか ら米国を中心にナノファイバー形成のメカニズムや応用
に関する研究が盛んになり，日本でも近年様々な検討が なされている.

エレクトロスピニング法は，他のナノファイバー作製 技術と比較して以下の特徵を挙げることができる.

(1)ナノファイバーの不織布（シート）が直接作製できる.

エレクトロスピニング法では, ナノファイバーが 2 次 元的に広がった形で形成される. そのため, 一旦紡糸し た後に, 改めて加工する必要が無いという利点がある. (2)室温でも紡糸可能.

エレクトロスピニング法は, 室温でも紡糸が可能であ るため，熱に不安定な化合物を含んだ溶液も紡糸でき る.

(3)幅広い材料に応用可能.

これまでに，ポリエステル，ポリアミドといった合成 高分子やコラーゲン, 絹, DNAといった天然高分子な ど，非常に多くの高分子について，エレクトロスピニン グ法によるナノファイバー形成が報告されている.また, 無機化合物や有機・無機ハイブリッド材料によるナノフ アイバーについても報告されている.

エレクトロスピニングの原理については未だに研究対 象となっているが，図1を用いて概略を説明する.

高分子溶液を入れたノズル先端に電圧を印加する，ま たは高分子溶液に直接電圧を印加することによって，以 下の現象が起こる.

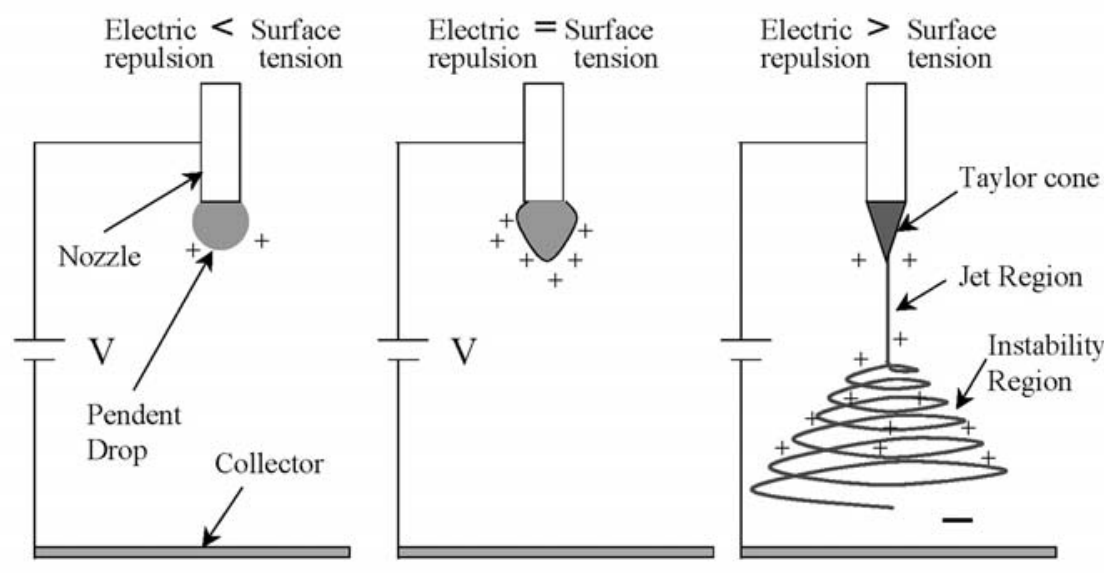

図1 エレクトロスピニング法の概念図 
(1)ノスル先端の液滴表面に電荷が集まり互いに反発す る.このときノズルから出た液滴は次第に円錐状と なる (Taylor cone).

(2)電荷の反発力が次第に強くなり反発力が表面張力を 超えたとき，液は円錐の先端から真っ直ぐに噴射さ れる。

(3)出された溶液流が細くなると表面電荷密度が大きく なるため，さらに電荷の反発力が増し，溶液流はさ らに引き伸ばされる。この際, 溶液流の表面積が急 速に大きくなることにより溶媒が揮発し, 捕集電極 上にナノファイバーが形成される.

この紡糸している状態を肉眼で観察すると, 円錐の先 端からある長さだけ真っ直ぐに溶液が噴出した後，突然 スプレー状に広がって見えなくなる．しかしながら，こ のスプレー状に見える部分を高速度カメラで観察する と, 真っ直ぐに噴き出ていた溶液流が蛇行を始め, その まま捕集電極へ向かって飛翔していることが確認されて いる ${ }^{4)}$.

エレクトロスピニング法においては, 電圧や溶液粘度, 表面張力, 溶媒の蒸発速度, 電気伝導度といった多くの パラメータが複雑に関連して，平均繊維径や繊維の均一 性などを決定している。また，作製条件によっては， 様々な表面構造や断面構造を有する超極細繊維を得るこ とも可能である，更に，捕集電極の形状により，シート 状，円筒状のものなど形状を自由にコントロールでき る.

エレクトロスピニング法ナノファイバーの実用化例と して，エアフィルターが挙げられる．例えば，米国ドナ ルドソン社は基材の上にナノファイバー層でコーティン グした構造のフィルターを販売している5).このような 構造とすることで, 高効率, 低圧力損失のフィルターが 得られるといわれている.

(1)高効率

フィルターに捕集される粒子の大きさと捕集効率の関 係を調べると，フィルターに用いる繊維の繊維径より粒 子が大きい場合や極端に小さい場合は捕集効率が高く,
その中間では捕集効率が低くなる，そこで，通常の繊維 よりなる基材と，ナノファイバー層を組み合わせること で双方が苦手とする範囲を補い合うことができ，すべて の大きさの粒子を高効率で捕集できるようになる.

(2)低圧力損失

セルロースからなる基材と, その上にナノファイバー 層をコーティングした積層体についてフィルター特性を 評価すると，同一ダスト粒子供給量で比較したとき，ナ ノファイバー層を有するほうが圧力損失は小さくなって いる，そのため，フィルターとして用いるときエネルギ 一消費が少なくてすむと考えられている.

先にも述べたように，エレクトロスピニング法では通 常ナノファイバーがシート状で得られる.しかしながら， 逆にシート状のサンプルしか得られないため，用途が限 定される問題があった。これに対して, 我々は紡糸条件 を制御することにより，綿状のナノファイバー構造体 (図2）やナノファイバーの撚糸（図3）を作製すること に成功しており，更に用途の幅が広がることが期待でき る.

\section{3. 有害化学物質分解除去用ナノ ファイバーの開発}

\section{1) 光触媒担持ナノファイバー不織布}

これまでに述べたように，エレクトロスピニング法に よって作製したナノファイバー不織布はミクロファイバ 一に比べて単位容積あたりの表面積が非常に大きいとい う特徴を持つ. 我々はこのナノファイバー不織布を触媒 担持体に用いると触媒担持効率が飛躍的に向上すること に着目した。そこで，触媒として光触媒を用い，VOC を光触媒反応で分解するコンパクトな VOC 分解除去モ ジュールの開発を検討した。

エレクトロスピニング法により，繊維径 $200 \mathrm{~nm}$ 程度 のPANナノファイバー不織布を作製し, 得られたナノ ファイバー不織布に光触媒をコーティングすることで, 光触媒ナノ粒子を担持したナノファイバー不織布を作製

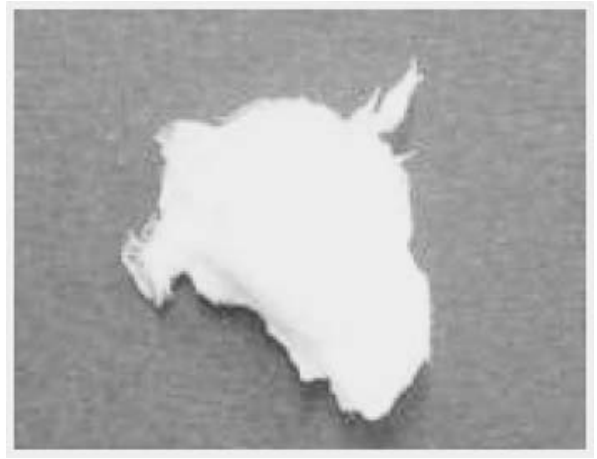

図2

綿状ナノファイバー構造体

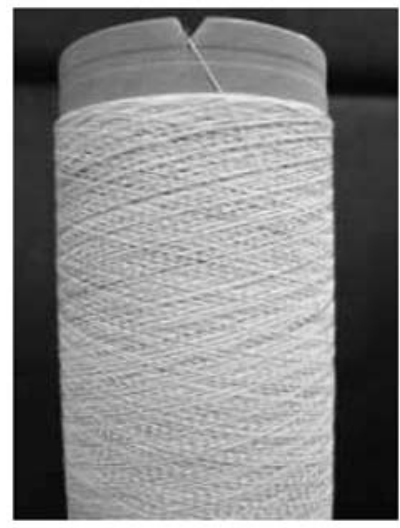

図3 ナノファイバー撚糸 
することができる (図 4). 䋊維径 $20 \mu \mathrm{m}$ の通常繊維よ りなる不織布に同様に光触媒コーティングを行った場合 と比べ，この光触媒担持ナノファイバー不織布の触媒担 持量は非常に大きい.すなわち，ナノファイバー不織布 は高効率な触媒担持体として用いることができる.

次に, この光触媒担持ナノファイバー不織布について, トリクロロエチレン（TCE）の分解活性評価を行った.

不織布の目付, 触媒担持量, UV 強度など, 不織布の 繊維径以外は全く同じ条件で検討すると, 通常繊維より なる光触媒担持不織布では, UV照射時間 60 分でも TCE は完全には分解しないが, 光触媒担持ナノファイバー不 織布では30分でTCEが完全に分解する.

すなわち, 光触媒を担持する繊維の径をミクロンオー ダーからナノオーダーとするだけで, TCE 分解効率が 極めて大きくなる.

\section{2) セラミックナノファイバー5)}

上述のように，ナノファイバーを用いると高効率な触 媒担持体として使用できる．しかしながら，光触媒をナ ノファイバーに担持した場合，ナノファイバー自身が光 触媒によって分解されることが危惧される.

そこで, 光触媒によって分解される恐れのない, 無機 のナノファイバー作製を検討した.

これまでも，エレクトロスピニングを用いた無機ナノ ファイバーについては数多く報告されている．しかしな がらそれらは非常に脆く, シートとして取り扱うことは 困難であった。
我々は，セラミック前駆体の構成や紡糸条件を検討し た結果, 様々なセラミックについて柔軟なナノファイバ 一不織布を作製することに成功した。

例えば，纎維径が $300 \mathrm{~nm}$ のアルミナナノファイバー が得られている（図5，6）。このアルミナナノファイバ 一不織布は高い耐熱性を有していることから, 光触媒担 持体以外にも，様々な応用が期待される.

また, 光触媒成分を含有するセラミックの一種である, Si-Ti-C-O 系繊維のナノファイバーの作製も可能である (図7,8).

この繊維は光触媒活性を有しながら, 優れた耐熱性も 兼ね備えた，非常にユニークな超極細繊維である.

さらには，100\%酸化チタンよりなるナノファイバー

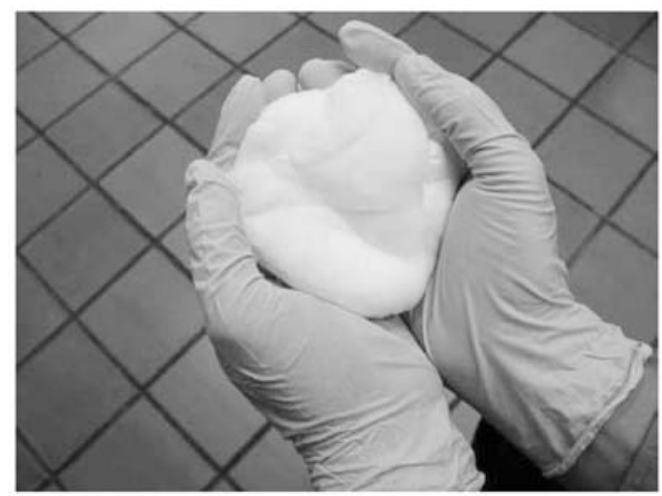

図5アルミナナノファイバー（綿状）の写真

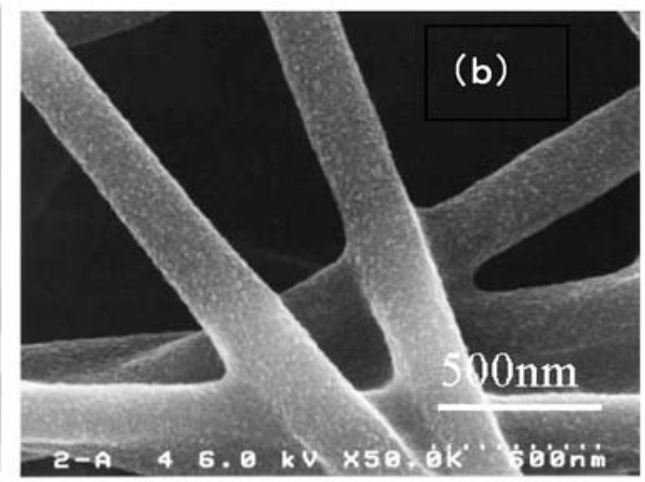

ธ่อ่อ่ñm

\section{(a)}

（a ）コーティング前、（b）コーティング後

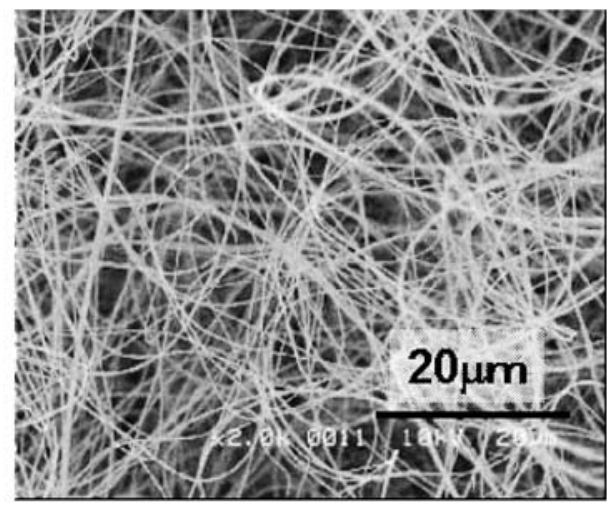

図6 アルミナナノファイバーのSEM写真

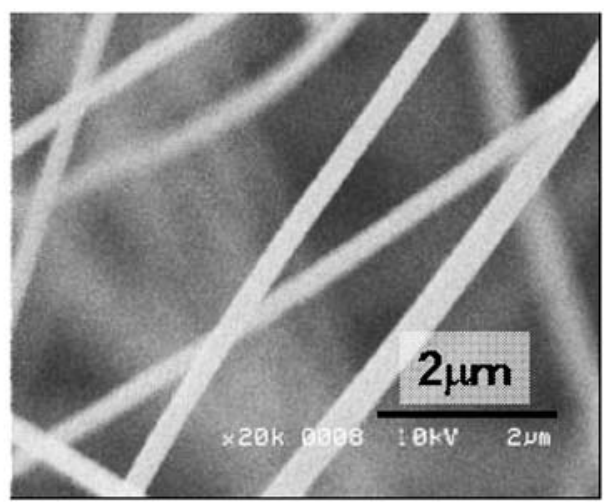


不織布の作製にも成功した（図9).この酸化チタンナ ノファイバーは，支持基材がなくてもシートとして取扱 いが可能であり，かつ光触媒活性を示す．そこで, 酸化 チタンナノファイバーと酸化チタン粉体との光触媒活性 を，メチレンブルーの退色反応を用いて比較した. なお， 酸化チタン粉体には, 粒径が50nmである市販のアナタ 一ゼ型酸化チタン粉体を使用した. ナノファイバーと粉 体について同重量で比較した場合，酸化チタンナノファ イバーの方が，酸化チタン粉体に対してより高い活性を 示すことがわかった（図 10）。

光触媒反応は, 酸化チタンの表面で行われることから, 一般に表面積の大きな酸化チタンの方がより高い活性を 示すことがわかっている. 作製した酸化チタンナノファ イバーは, 従来の酸化チタン繊維に対して大きな表面積 を有しているとはいえ, 酸化チタン粉体よりは表面積は 小さいことから，この考えでは説明ができない.

そのため今回の結果は, 粒子の凝集による効果が関係 しているのではないかと考えている．酸化チタン粒子は 大きな表面積を有しているが，凝集しやすいために実際 に反応に寄与する表面積が小さくなっていると思われ る. 一方, 酸化チタンナノファイバーは, 䋊維形状を有 することによって凝集が抑えられ，水中でも大きく広が った形状を維持しており, その結果, 高い光触媒活性を 示したと理解できる. 支持体を必要とせずに取り扱うこ とも可能であり, 有害化学物質分解除去はもちろんのこ と, 様々な応用が期待される材料である.

\section{4. おわりに}

エレクトロスピニング法は様々なポリマーのみならず セラミックなどの無機化合物にも応用でき, 汎用性の極 めて高いナノテクノロジーの一つといえる. また, 高分 子/高分子, 無機化合物/高分子などのブレンド溶液に も適用できるため, 材料設計の自由度も非常に大きい.

今後は，このエレクトロスピニング法を活用し，従来 の手法では得られなかった新たな機能性不織布を開発し ていきたい.

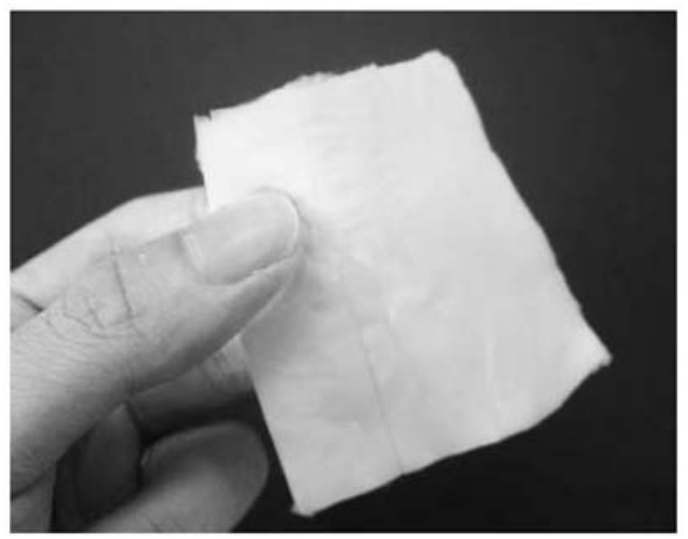

图7 Si-Ti-C-O系セラミックナノファイバーの写真
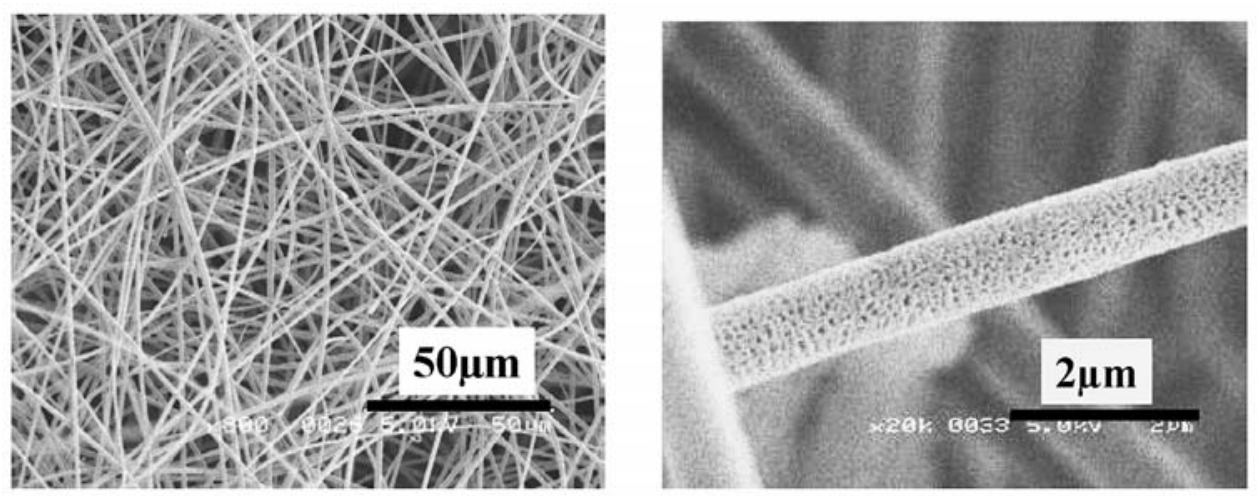

图8 Si-Ti-C-O系セラミックナノファイバーのSEM写真

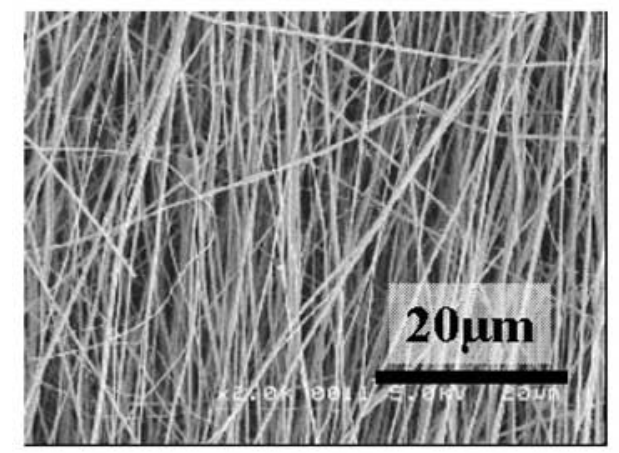

図9酸化チタンナノファイバー不織布のS E M 写真

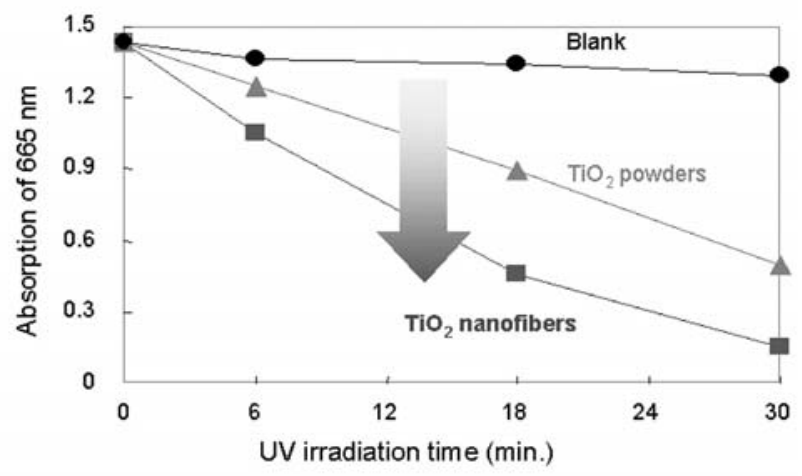

図10 酸化チタンナノファイバーの光触媒活性の測定結果 


\section{参考文献}

1) 本宮達也監修：「ナノファイバーテクノロジーを用いた高 度産業発掘戦略」, シーエムシー出版, (2004)

2) 北䓟英一，兼子博章，三好孝則，宮本啓一：有機合成化学 協会誌 62(5), 514 (2004)
3) A. Formhals : US Patent 1,975,504 (1934)

4) D. H. Reneker, A. L. Yarin, H. Fong, S. Koombhongse,: J. Appl. Phys., 8 7, 4531 (2000)

5) 本宮達也：「図解よくわかるナノファイバー」，日刊工業 新聞社, (2006)

6) 小村伸弥，三好孝則：ポリマー材料フォーラム予稿集 36 (2005)

\title{
三好孝則 (みよしたかのり)
}

1992 年, 九州大学大学院工学研究科合成化学専攻修士課程修了. 同年, 帝人株に入社. 高分子材料の基礎，応用研究に従事. 2002 年よりナノファイバーの研究開発に従事. 現 在, 先端技術開発センター主任研究員.

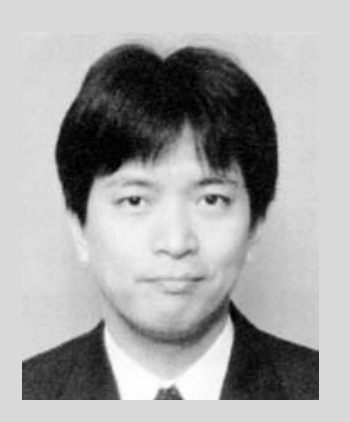

\section{海外資料研究会入会ご案内}

\section{世界各国の繊維技術情報を}

\author{
より早く,より広く,より正確に把握するために
}

\section{海外資料研究会へご入会下さい}

本学会海外資料研究会におきましては, 海外各国から, 我が国にもたらされる, 繊維に関する数多くの情報を逐 一検討し，それらを工程別，分野別に分類，整理の上，速やかに訳出し，「海外纎維技術文献集」を通じて定期的に おとどけしています.

世界各国における研究状況, 技術開発および市場動向等, いち早くその関連業界の流れを的確に把握するため, 本研究会へのご入会をおすすめします.

\section{1. 海外文献, 資料の蒐集整備}

\section{事 業 内容}

海外各国より毎月多数の文献, 資料, 所報, 社報, カ夕ログ等を入手しており, これらの整備充実をはかり, その内容を訳出し て会員に紹介しています.

2. 海外繊維技術文献集 (隔月刊) の刊行

毎月入手する多数の文献や資料等をそれぞれの分野の専門の委員によって, 工程別に分類, 整理の上, 速やかに訳出して紹介す る海外繊維文献抄録と，繊維並びに繊維機械に関する基礎的研究論文，実際的研究および新製品や新しい技術の紹介等，比較的 重要と思われるものについては全訳して紹介する海外瀻維技術文献集を合冊して, 機関誌として定期的におとどけします. 編集, 訳出, 査読等は全国各大学, 研究所並びに会社所属の専門の方々に依頼し，その正確流暢を期しています.

3. 海外文献紹介講演会, 座談会の開催

海外文献に掲載されたもののうち注目すべきもの，あるいは海外で行われた講演会，シンポジウム並びに見本市等につき，随時 紹介講演会, 座談会を開催します.

4. 海外文献, 資料の複写頒布

会員に限り，本会所有の文献，資料の複写頒布を行っています.

5. 申込方法

申込書をご請求下さい，見本誌を進呈しますので，ご希望の方はお申し出下さい.

部会費 (割引購読料) 年間 12,600円 (消費税込み)

̄ 550-0004 大阪市西区勒本町 1-8-4（大阪化学技術センタービル）

日本繊維機械学会 海外資料研究会 TEL. 06-6443-4691, FAX. 06-6443-4694 